\title{
越波・越流の遷移過程を高精度化した高潮浸水計算モデルの開発
}

\section{Numerical Simulation Model for Storm Surge Inundation Incorporating Accurate Estimation of Transition Process from Overtopping to Overflow}

\author{
鈴木 武 $^{1} \cdot$ 柴木秀之 ${ }^{2}$ \\ Takeshi SUZUKI and Hidenori SHIBAKI
}

\begin{abstract}
A numerical simulation model for storm surge inundation has been developed. Inundation simulation method induced by transition process from overtopping to overflow is incorporated into this model. Convenient estimation method for this transition process is based on the equations produced by Goda(1975a). Several parameters in the Goda's equations are revaluated by numerical wave simulations of the transition process from overtopping to overflow. These simulations are performed by using VOF method (CADMAS-SURF). According to these simulation results, accurate flow rates over the coastal dikes are estimated at the time of storm surge. With this simulation model, high storm surges generated by large typhoons around the coasts of Japan can be reproduced. This paper presents the outline of the simulation model for storm surge inundation.
\end{abstract}

\section{1. はじめに}

日本沿岸では, 高潮・高波による浸水災害がたびたび 発生している。.さらに，近年注目されている地球温暖化に 伴う海面上昇と台風の強大化は，高潮，高波による浸水被 害の増大をもたらす。そうした高潮，高波の脅威の増大に 備えるため，ハード対策とソフト対策を効果的に組み合わ せた浸水被害への対応が望まれる，適切な浸水被害対策を 考えるうえで, 高潮浸水シミュレーションによる浸水範囲 及び浸水被害の想定が有効である。しかし, 越波と越流が 共存する高潮時の浸水予測計算に打いて, 越波から越流へ の遷移過程の流量（越波・越流量）については，一般的な 計算法が確立されていない。越波から越流への遷移過程の 流量算定の試みとして，山下（2008）らは，VOF法によ る計算結果をもとにリーフ上での越波・越水の計算モデル を提案している. しかし，平均水位が護岸天端より高い条 件の検討が少なく, 詳細は記述されていない。一方，柴木 ら（2008）は，合田（1975a）の期待越波流量算定図の外 捚値と本間公式 (1985) を併用し, 高潮浸水シミュレーシ ヨンに組込む便宜的な方法を採用した。しかし，計算精度 の課題が残った．高潮浸水予測計算の精度を高める上で, 高波による越波と高潮潮位による越流の計算精度を高める ことは重要である。本研究では，CADMAS-SURFによる 数值計算結果により検証された越波・越流量を一体的に計 算できる期待越波・越流計算モデルを構築する。そして, この計算モデルを高潮時の浸水計算に導入し, 越波から越 流への遷移過程を精度良く評価するための高潮浸水計算法

1 正会員博(工) 国土技術政策総合研究所港湾研究部長

2 正会員 博 (工) (株) エコー防災・水工部長
を提案する.

\section{2. 期待越波・越流計算モデルの概要}

\section{（1）既往の越波・越流計算}

柴木ら（2008）の高潮浸水シミュレーションの越波・ 越流計算法（既往モデル）は，時間変化する潮位と波浪 情報から, 時間平均量としての越波流量を近似的に求め ることが可能であり，実用性は高い。しかし，越波・越 流量は，本間公式（1985）を用いると越波の影響が含ま れないため, 平均水位が護岸天端に近い場合に過小評価 となる。また，期待越波流量算定図では， $h c / H 0^{\prime}<0.5$ (堤防天端高と平均水位の差 $h c$, 平均水位が堤防天端高 より低い場合を正として表現）の条件の事例がないため, 算定図の外抻処理により流量を求めている。 そして，両 者の結果から, 流量が不連続にならないように選択した。 そのため, 越波・越流量の計算精度上, 課題が残るもの であった。

\section{（2）越波から越流への遷移過程の流量}

著者ら（2010）は，越波から越流への遷移過程の現象 を, 複数の平均水位及び波浪条件を設定した数值波動水 路（VOF法：CADMAS-SURF 5.1，（財）沿岸技術研究七 ンター（2008））を用いた護岸通過流量の算定シミュレ ーションにより表現した。図-1は，合田の期待越波流量 算定図中に, 護岸通過流量のシミュレーション結果を重 ねたものである。平均水位が護岸天端高より低い $\left(h c / H_{0}{ }^{\prime} \geqq 1 / 2\right)$ 場合は, 算定図の流量を良く再現している. そして, 水位が増加するとともに越波・越流量は増加し, 水位が護岸天端高を超過する $\left(h c / H_{0}{ }^{\prime} \leqq 0.0\right)$ と, 通過流 量は水深の変化に大きく依存しないことがわかる. 図-1 の平均水位が高い越流の状況 $\left(h c / H_{0}{ }^{\prime} \leqq 0.0\right)$ について, 


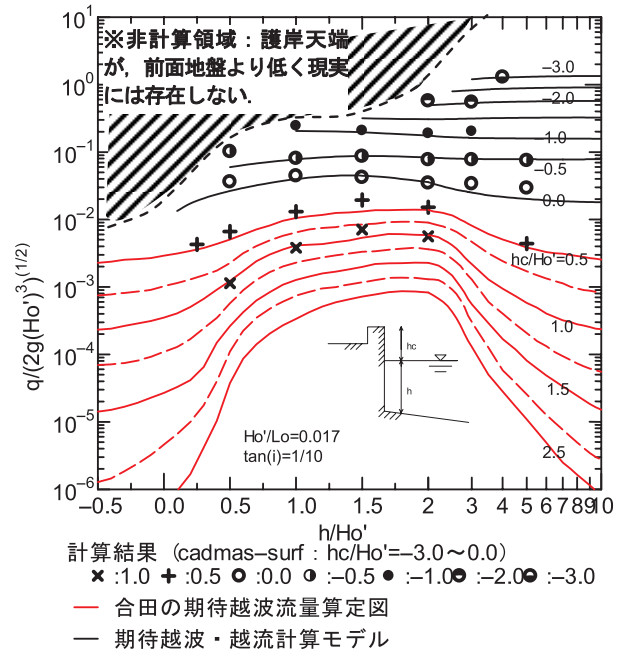

図-1 水位上昇昇時の期待越波・越流量の変化状況（直立堤）

通過流量のシミュレーション結果を近似する複数の直線 を併記する。これら直線は, 後述する期待越波・越流計 算モデルにより算定される流量を表す.

\section{（3）期待越波・越流計算モデル}

著者ら（2010）は，式（1）～式（3）に示す期待越波流 量算定図の基本となる合田モデル（不規則波の砕波変形 モデルと越流せきとしての越波量計算）を引用し，モデ ル中のパラメー夕調整を行うことにより, 越波から越流 に遷移する過程の流量計算モデル（期待越波・越流計算 モデル）を提案している.

$$
\begin{aligned}
& \frac{q_{\exp }}{\sqrt{2 g\left(H_{O}^{\prime}\right)^{3}}}=\int_{0}^{\infty} q^{*}(x) p(x) d x \\
& q^{*}=\frac{q(x)}{\sqrt{2 g\left(H_{O}^{\prime}\right)^{3}}}=A_{0}\left(\frac{K}{1+K}\right)^{3 / 2} x^{3 / 2}\left[1-\frac{h_{C}}{H_{O}^{\prime}} \cdot \frac{1}{K x}\right]^{5 / 2} \\
& K=\frac{\eta_{C}}{H}=\min \left\{\left[1.0+a \frac{x H_{O}^{\prime}}{h}+\frac{b}{K_{s b}}\left(\frac{x H_{O}^{\prime}}{h}\right)^{2}\right], c\right\} \cdots
\end{aligned}
$$

ここに, $A_{0}$ ：越流係数に対応する係数 $(0.10)$, $x=H / H_{0}{ }^{\prime}, p(x)$ : 無次元波高 $x$ の確率密度関数, $K_{s b}=H_{1 / 3}$ $/ H_{0}{ }^{\prime}$ : 非線形浅水効果及び砕波減衰による有義波高変化 率, $K$ : 波頂波高比, $\min \{A, B\}: A$ または $B$ のいずれか小 の值である。

なお, 無次元波高 $x$ の確率密度 $p(x)$ は, 深海域の確率密 度をレーリー分布とし，合田（1975b）の不規則波の砕 波変形モデルによって計算される。波浪条件となる $H_{0}{ }^{\prime} L_{0}, h / H_{0}{ }^{\prime}$ と海底勾配は, 確率密度 $p(x)$ に含まれる。 ま た, 間接的に, 浅水変形, 砕波変形, 水位上昇やサーフ ビートの効果も含まれている.

期待越波・越流計算モデルは，合田（1975a）の期待
越波流量算定図及びCADMAS-SURFの越波・越流量の計 算結果を精度良く計算できるように，式(2) の係数を調 整している. 式(3) 中の係数には, $a=1.0, b=0.8$ を用い, 係数 $c$ は, 式(3) 右辺の $H$ に砕波限界波高を, hに砕波限 界水深を入力して計算される值を採用する.これにより, 係数 $c$ は図-2のように設定する。また，Kが大きくなるの に従い短縮される波の山の継続時間も，平均水位が護岸 より高い場合について修正を加えた。

期待越波・越流計算モデルにより計算される流量の結 果を図-3に実線で表す。図は, 海底勾配 1/30, 直立堤で, $H_{0}{ }^{\prime} / L_{0}=0.017$ の場合の算定結果である.

$h / H_{0}{ }^{\prime}>1.0, h c / H_{0}{ }^{\prime}$ が大きい条件で, 計算モデルの結果 は合田（1975）の期待越波流量算定図の值と良く一致す る. 一方, $h / H_{0}{ }^{\prime}<1.0$ の条件では, 波が非線形化するとと もに急激な変形が生じ, 砕波, 研波後の流れ, ウェーブ セットアップ等の複雑な現象となる, それに伴い, 両者 の違いが顕著となる. 図-3に表す期待越波・越流計算モ デルは，モデル中のパラメー夕調整により, 越波から越 流に遷移する過程の流量を連続的に推定できる.

\section{3. 高潮浸水シミュレーション}

\section{（1）期待越波・越流計算モデルの高潮浸水計算への導入}

図-4 はCADMAS-SURF の結果と本間の越流公式 (1985) による流量の算定結果を比較したものである．図による と, 平均水位が護岸天端高に近い場合は越波量が卓越し, 越流量は過少となり, 平均水位が護岸天端高を超過する とともに, 本間公式（1985）（越流係数 0.35 に相当）の 越流量よりも小さくなる。この場合の越流係数は 0.20 0.25 程度となり, 越流量の $2 / 3$ 程度の流量となる. 既往モ デルは, 越流状態で越流公式を採用することから, 護岸 背後の浸水量も過大になると予想される.

ここでは, 非線形長波理論に基づく高潮浸水計算シミ ユレーションに期待越波・越流計算モデルを導入し, 計

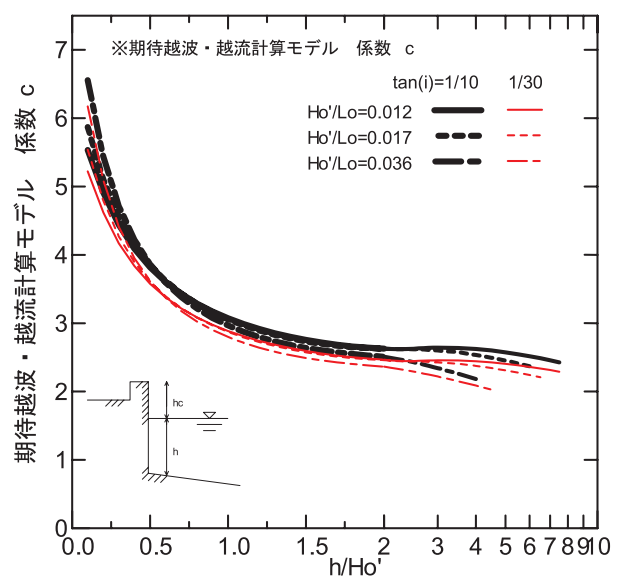

図-2 期待越波・越流計算モデルの係数 $\mathrm{c} の$ 変化 


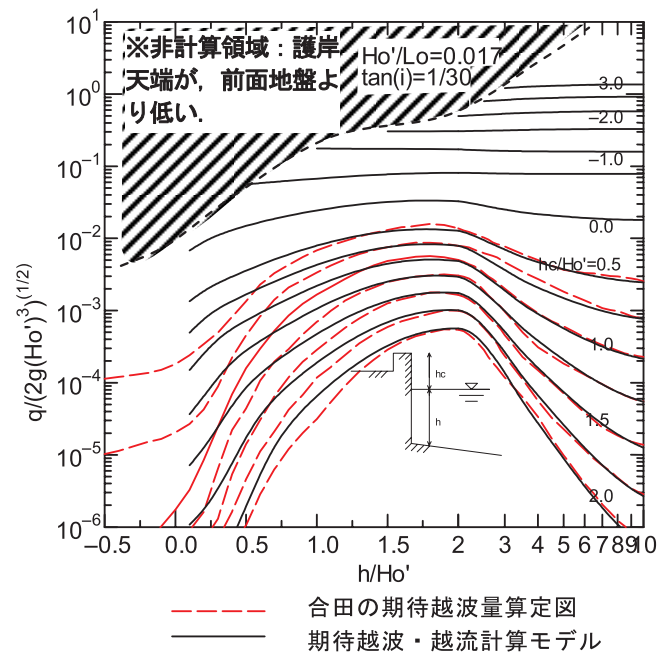

図-3 期待越波・越流計算モデルによる流量算定結果

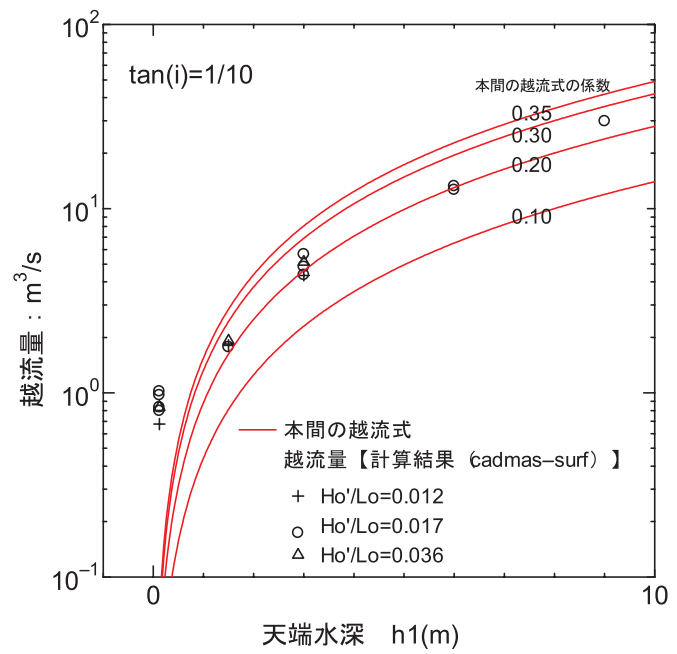

図-4 越流公式と数值シミュレーション結果の比較

算精度を高める。高潮浸水計算は，越波・越流量の計算 以外，柴木ら（2008）のモデルを用いる. 越波・越流量 は，高潮計算，波浪推算，波浪変形計算より求まる護岸 前面の潮位と波浪を入力条件とし，期待越波・越流計算 モデルで計算する。ただし，CADMAS-SURFを用いた護 岸通過流量の検討では, 護岸前面とその背後の水位差の 影響を考慮していない. 従って, 越波・越流からもぐり 越流に遷移する過程，陸側からのもどり流れの影響など が明確になっておらず，期待越波・越流計算モデルでは， このような現象を計算することができない，そこで，図-5 に示す, 高潮浸水計算時の越波・越流の代表的な現象 に対して，護岸前面及びその背後の水位の関係により， 式（4）と式（5）に示す本間の越流公式（1985）を併 用する。

$$
\begin{aligned}
& q=\mu h_{1} \sqrt{2 g h_{1}} \quad \text { （完全越流）…............. } \\
& q=\mu h_{2} \sqrt{2 g\left(h_{1}-h_{2}\right)} \quad \text { (もぐり越流） }
\end{aligned}
$$

ここに， $\mu$ : 越流係数（完全越流：0.35, もぐり越 流 : 0.91), $h_{1}, h_{2}$ : 護岸前後の越流深 (図-5参照), 完 全越流の条件 $: h_{2} / h_{1}<2 / 3$, もぐり越流の条件 $: h_{2} / h_{1}>2 / 3$ である。

Type1は，浸水に対し越波による寄与が高い場合で, 平均水位が護岸天端に近い条件である。Type2は, $h c / H_{0}{ }^{\prime}<-0.5$ 程度から見られる現象であり, 越波及び越流 が同時に生じる。これらの現象の遷移過程を連続的に表 現するために，期待越波・越流計算モデルは有効である. Type3のように浸水が進行すると, 海域側と陸域側の水 位差が小さくなり，もぐり越流が生じる．この場合は背 後の水位も大きくなり $\left(h_{2}>1 / 2 H\right.$ 程度の水位), 式 (5) のもぐり越流の式から算定される流量に置き換える. Type4 は, 護岸前面の平均水位より, 背後地の水位が高 い場合であり，陸側からのもどり流れが生じる。この場 合は，期待越波・越流計算モデルとともに， $h_{2} / h_{1}<2 / 3$ の 場合に式 (4) の完全越流の式を, $h_{2} / h_{1}>2 / 3$ の場合に式 （5）のもぐり越流の式も併用する。すなわち, 期待越 波・越流計算モデルによる海側からの流量と式 (4) また は式 (5) による陸側からのもどり流れの流量の差分值を 求める。ただし，背後水位が護岸天端よりも十分高い場 合 $\left(h_{1}>1 / 2 H\right.$ の水位), 式(4) または式(5)により，もど り流れの流量のみを求める.

\section{(2) 高潮浸水計算条件}

広範囲の低平地が存在する伊勢湾奥部を対象に，期待 越波・越流計算モデルを導入した高潮浸水シミュレーシ ヨンを適用する，台風条件は，伊勢湾台風の中心気圧深 度の 1.3 倍を，台風コースは伊勢湾台風コースとする。 また，潮位条件として，伊勢湾奥部のH.W.L.に，地球温 暖化による水位上昇量として $60 \mathrm{~cm}$ を加えた值を設定す る。なお，台風条件および潮位条件は，越波，越波·越 流，越流による浸水が比較できる条件を選定している. 高潮推算及び波浪推算の計算範囲は，台風経路を含む太 平洋の広域を確保する，計算地形は，伊勢湾海域を $200 \mathrm{~m}$ ～600m 格子で近似し，湾奥抒上び浸水想定区域（陸上 域）を $100 \mathrm{~m}$ 格子で近似する。

\section{（3）伊勢湾奥部の高潮浸水計算結果}

背後域の浸水範囲と, 越波・越流量の時系列に関して, 本論文の提案モデルと既往モデルの浸水予測結果を比較 し，提案モデルの特徵をまとめる. 図-6は浸水範囲の比 較結果である．比較を行う地点は，越波の寄与が大きい 浸水区域前面の地点（PT.1）と, 越波と越流が同時に作 用する浸水区域前面の地点（PT.2）を選定する。また， 
図-6には，越波・越流が同時に発生するPT.2の背後を抽 出し, 浸水範囲の拡大図とその浸水面積も示している.

越波の寄与が大きいPT.1の背後域は, 両者に顕著な差 が見られない。図-4によると, 越波の寄与が大きい条件 では，本間公式で計算される既往モデルより，期待越 波・越流計算モデルを導入した高潮浸水モデルにより予 測した浸水範囲の方が大きくなると推測される. しかし, この背後域は, 浸水範囲も狭く, 護岸からの通過流量も 小さいため，顕著な差がなかったと考えられる。一方， 越波・越流が同時に発生する. PT.2の背後域は, 抽出し た範囲の浸水面積をみると, 既往モデルで $0.236 \mathrm{~km}^{2}$, 期 待越波・越流計算モデルで $0.216 \mathrm{~km}^{2}$ となり，期待越波・ 越流計算モデルを導入した高潮浸水モデルにより予測し た浸水範囲が 0.915 倍程度小さくなる.図-4は2/3程度の 護岸通過流量の差異が生じることを示しているが, 既設 護岸前面に人工島, 埋立地などが設けられた境界条件で は，浸水面積に顕著な差異が生じていない.

これら護岸前面2点について, 越波から越流への遷移 過程の流量の時系列を求め, その違いを解析する. 図-7,

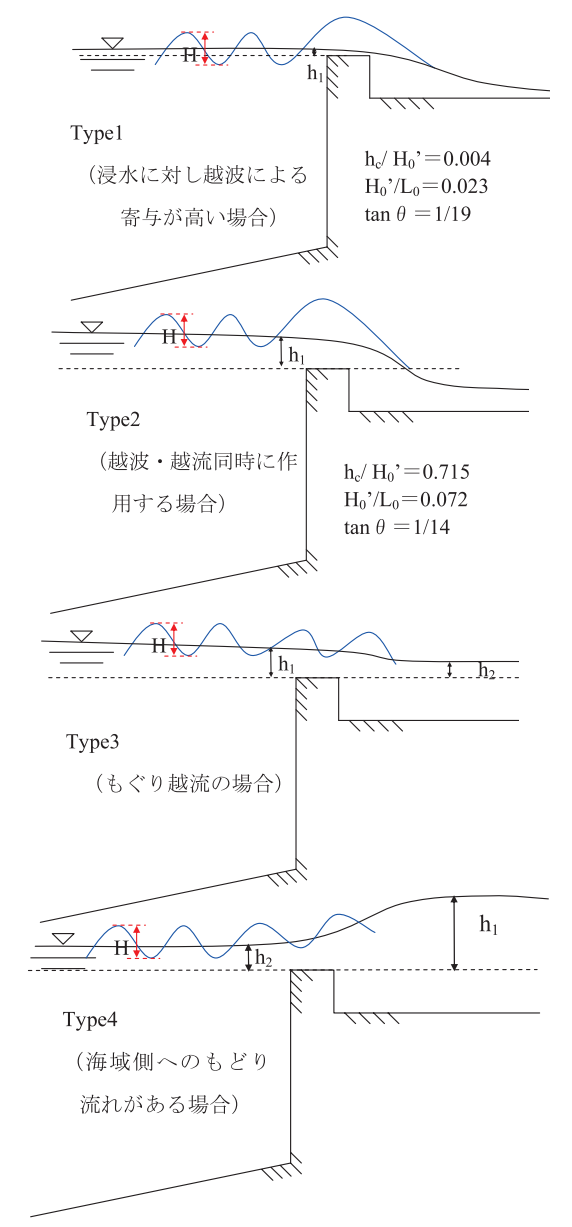

図-5 高潮時に発生する越波・越流状況の模式図
図-8は, 構造物前面の潮位および波浪の時系列, 期待越 波・越流計算モデルと既往モデルから求まる越波・越流 量の時系列の比較である。これらの潮位, 波浪の計算值 を期待越波・越流計算モデルに入力し, 越波・越流量を 計算する.PT.1の前面水位は, 潮位のピーク時でも $h c / H_{0}{ }^{\prime}=-0.004$ であり, 潮位と波浪の時系列からも, 越波 が支配的であることが確認できる。一方, PT.2は, 潮位 ピーク時の前面水位が $h c / H_{0}{ }^{\prime}=-0.715$ となり, 波高も $0.5 \mathrm{~m}$ 程度であるため, 越波と越流が共存する条件となる.

PT.1の越波流量は，期待越波・越流計算モデルと既往 モデルで良く一致する。 そして, 平均水位が護岸天端高 を超過すると, 既往モデルは越流量を計算するため過小 評価となる。それに対し, 期待越波・越流計算モデルは 流量の連続性を保ち, 引き続き流量が増加する結果とな る. 一方, PT.2のように平均水位が護岸天端高を大きく 超過して越流量が大きい場合は，図-4の結果と同様に， 既往モデルで算定される越流量の $2 / 3$ 程度の流量となる.

\section{4. 埋立地の越波・越流量の分析}

期待越波・越流計算モデルでは，護岸前面及び背後の 平均水位により本間公式（1985）も併用する。このよう な状況は, 埋立地等の浸水が顕著な陸域で確認できる.

図-9は，陸側からのもどり流れがあるPT.3（図-6参照）
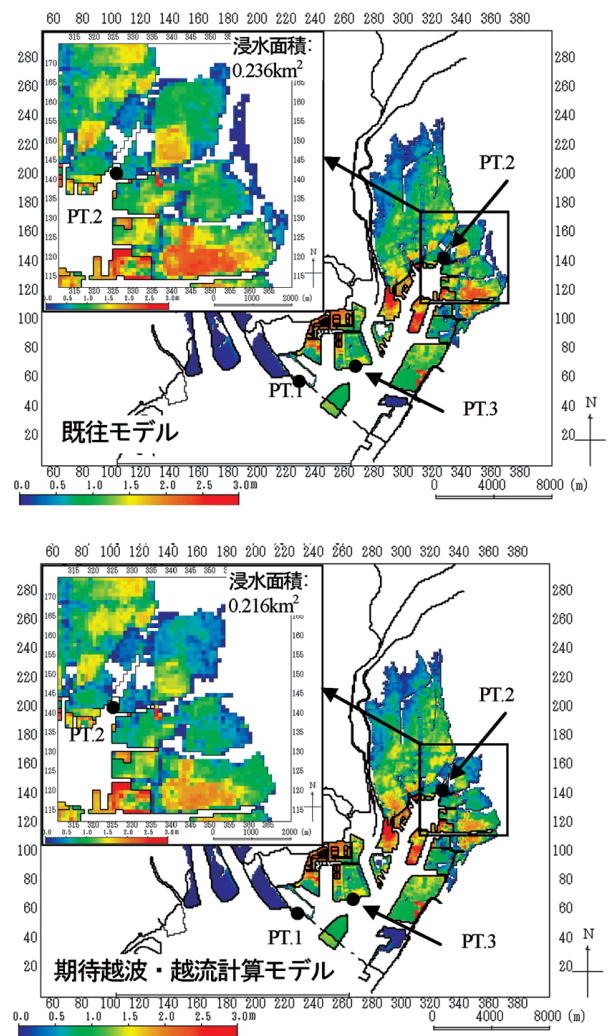

図-6 期待越波・越流計算モデルと既往モデルの浸水範囲 

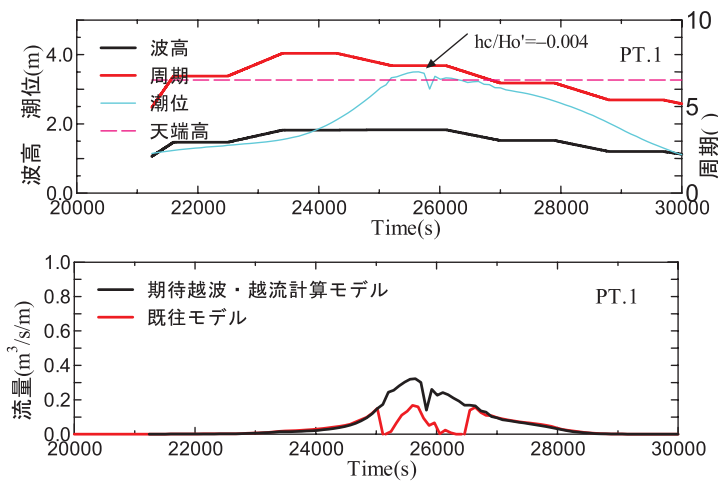

図-7 構造物前面の潮位・波浪・流量経時変化 $(\mathrm{PT} .1)$
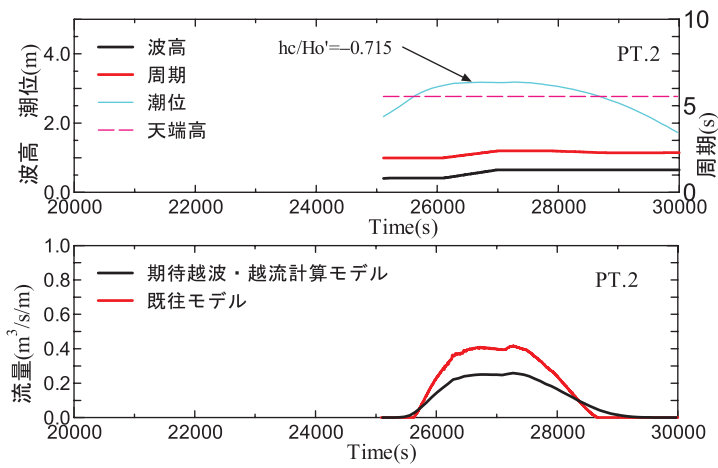

図-8＼cjkstart構造物前面の潮位・波浪・流量経時変化（PT.2）

の越波・越流量及び波浪，潮位の時系列である。図は， もどり流机が生じる越波, 越波・越流, もぐり越流へ遷 移過程の区間を抽出した状況である。もぐり越流へ移行 後は既往モデルと同様な変化を見せる．図の $21,000 \mathrm{~s} \sim$ 22,300s 間は越波が支配的であり，期待越波・越流計算 モデルによる計算流量が採用される。それに対し， 22,300s〜24,200s 間は，陸側からの戻り流れが発生し， 期待越波・越流計算モデルと本間公式（1985）による算 定流量の差分值が採用される.さらに，24,200s 以降は, 陸域と海域の水位差が小さくなり，もぐり越流が生じる ため，本間公式（1985）による算定流量が採用されるこ とになる。

\section{5. 主な結論}

期待越波・越流計算モデルを導入した高潮・高波共存 時の高潮浸水シミュレーションモデルを提案した。 以下 に主な成果をまとめる。

（1）期待越波・越流計算モデルによる護岸通過流量は, CADMAS-SURFによる計算結果を反映し，越波状態か ら越流状態への遷移過程の流量の精度向上を図った.

（2）期待越波・越流計算モデルを導入した高潮浸水シ



図-9 高潮浸水計算時の越波・越流量の時系列の分析

ミュレーションを伊勢湾奥部に適用し，浸水計算法 の機能を確認した．越波から越流への遷移過程の流 量を連続的に算定できる実用的な高潮浸水モデルが 構築できた。

今後，護岸前面とその背後の水位差の影響を考慮した 越波・越流量，越波・越流から越流に遷移する過程，越 流に対して波浪の影響が生じない境界，陸側からのもど り流れの影響などの検討を進め，期待越波・越流計算モ デルの精度向上に取り組む予定である。

\section{参 考 文 献}

（財）沿岸技術研究センター（2008）：CADMAS-SURF実務 計算事例集，沿岸技術ライブラリーNo.30.

合田良実・岸良安治・神山 豊（1975a）：不規則波による防 波護岸の越波流量に関する実験的研究，港湾技術研究所 報告，第 14 巻， 4 号，pp.3 44.

合田良実（1975b）：浅海域における波浪の砕波変形，港湾技 術研究所報告, 14卷, 3号, pp. 59-106.

柴木秀之・鈴山勝之・江崎竜夫（2008）：越波と越流を考慮 した高潮浸水の数值計算, 海洋開発論文集, 第 24 巻, pp. 459-464.

鈴木 武・柴木秀之（2010）：潮位の上昇に伴う越波から越 流への移行過程における流量算定手法, 海洋開発論文集, 第26巻, pp. 399-404.

土木学会編 (1985) : 水理公式集, pp. 284-288.

山下隆男 - 仲村佳輝 - 宮城栄喜 - 岡 秀之 - 西岡陽一 - 竹内 仁・喜屋武昂・星 宗博（2008）：沖縄県沿岸域におけ る津波・高潮浸水・被害予測, 海岸工学論文集, 第 55 巻, pp. 306-310. 